\title{
A thematic issue on current developments of economic geology research in Finland
}

\author{
Pasi Eilu ${ }^{1}$ (D) Ferenc Molnár $^{1} \cdot$ Petri Peltonen $^{2}$ \\ Received: 11 August 2020 / Accepted: 10 September 2020 / Published online: 19 September 2020 \\ (C) Springer-Verlag GmbH Germany, part of Springer Nature 2020
}

Finland is in the centre of the Precambrian Fennoscandian shield (Fig. 1) with a geology similar to other mineral-rich shield areas of the world, such as Western Australia, South Africa and Canada, and has a long tradition in mining and related industries. Unlike many other parts of Europe, Finland currently has a large number of active metal mines and smelting capacities, and still has a major potential for new significant mineral discoveries (Weihed et al. 2005; Eilu 2012; Eilu et al. 2020). This thematic issue is another contribution to indicate the significant mineral potential of Finland and may also encourage work in other parts of Europe, which are largely (and surprisingly) under-explored.

The acknowledged mineral potential of the Fennoscandian shield is reflected by the fact that, for a decade, Finland's share has been about $25 \%$ of all budgeted mineral exploration within the EU, and that of Sweden only slightly less. This figure distinctly describes how important mining and exploration companies see the Fennoscandian shield. This attractiveness is also shown by the annual reports of the Fraser Institute, where Finland has been in the global top ten countries with favourable mining jurisdiction for a decade; in 2019, Finland was seen as having the best policy climate for mining investment in the world (Stedman et al. 2020).

The main targets in metal exploration and mine development projects in Finland have for a long time been $\mathrm{Au}, \mathrm{Co}, \mathrm{Cu}$, $\mathrm{Ni}$, PGEs, and $\mathrm{Zn}$. The most recent additions to the actively explored commodities include the 'battery metals' (e.g. Co, $\mathrm{Li}, \mathrm{V}, \mathrm{Ni}, \mathrm{Cu}$ ) and graphite. The current ore geology research in Finland is focused on the refinement of exploration models,

Editorial handling: B. Lehmann

Pasi Eilu

pasi.eilu@gtk.fi

1 Geological Survey of Finland, PO Box 96, 02151 Espoo, Finland

2 Department of Geosciences and Geography, University of Helsinki, P.O. Box 64, FI-00014 Helsinki, Finland assessments of regional mineral potential, development of new exploration tools with better capacities for vectoring towards ores, and gathering new knowledge of mineral systems (Maier 2015; Rasilainen et al. 2016; Makkonen et al. 2017; Molnár et al. 2020). As Precambrian mineral belts are the major global sources of many types of ores, the results of studies completed in Finland are also applicable to mineral exploration on other shield areas.

The papers of this thematic issue present the current achievements of research on magmatic Ni-Cu-PGE, scandium bearing Fe-Ti-P, gold-rich $\mathrm{Cu}-\mathrm{Zn}$ VMS, orogenic gold, and graphite deposits (Fig. 1). It is expected that the topics of this thematic issue will generate broad international interest, and it is also expected that it will further boost exploration interest in Finland.

Moilanen and co-authors document magnetite and chromian magnetite compositions in several Ni-Cu-PGE deposits (overview in Maier 2015) in a range of mafic to ultramafic host rocks, and in apparently non-mineralised komatiite sequences across northern and eastern Finland. Their most significant finding is the positive correlation between the $\mathrm{Ni}$ content in oxide with the $\mathrm{Ni}$ tenor of the sulfide phase in equilibrium with magnetite, independent of whether the sulfide assemblage is magmatic or post-magmatic in origin. Another feature relevant to exploration is that the presence of nickeliferous sulfide inclusions in magnetite can be utilised as a possible vector to ore. As the oxides typically have a better survival potential in weathered and transported media, the work by Moilanen et al. also gives tools for exploration in glaciated and other terrains covered by soil, using soil geochemistry and indicator-mineral compositions.

Järvinen and co-authors present a revised magmatic stratigraphy for the 2.44 Ga Näränkävaara mafic-ultramafic body, one of the layered intrusions in the northern Fennoscandian shield. These intrusions were emplaced during the Palaeoproterozoic rifting of the Archaean basement, at ca. $2.45 \mathrm{Ga}$, and host numerous reef, contact and offset-type PGE(-Ni-Cu) deposits, as well as Cr-Fe-Ti-V deposits (Iljina 
Fig. 1 Main geological features of the Finnish bedrock and locations of deposits and occurrences discussed in this thematic issue. Geology according to the GTK bedrock database

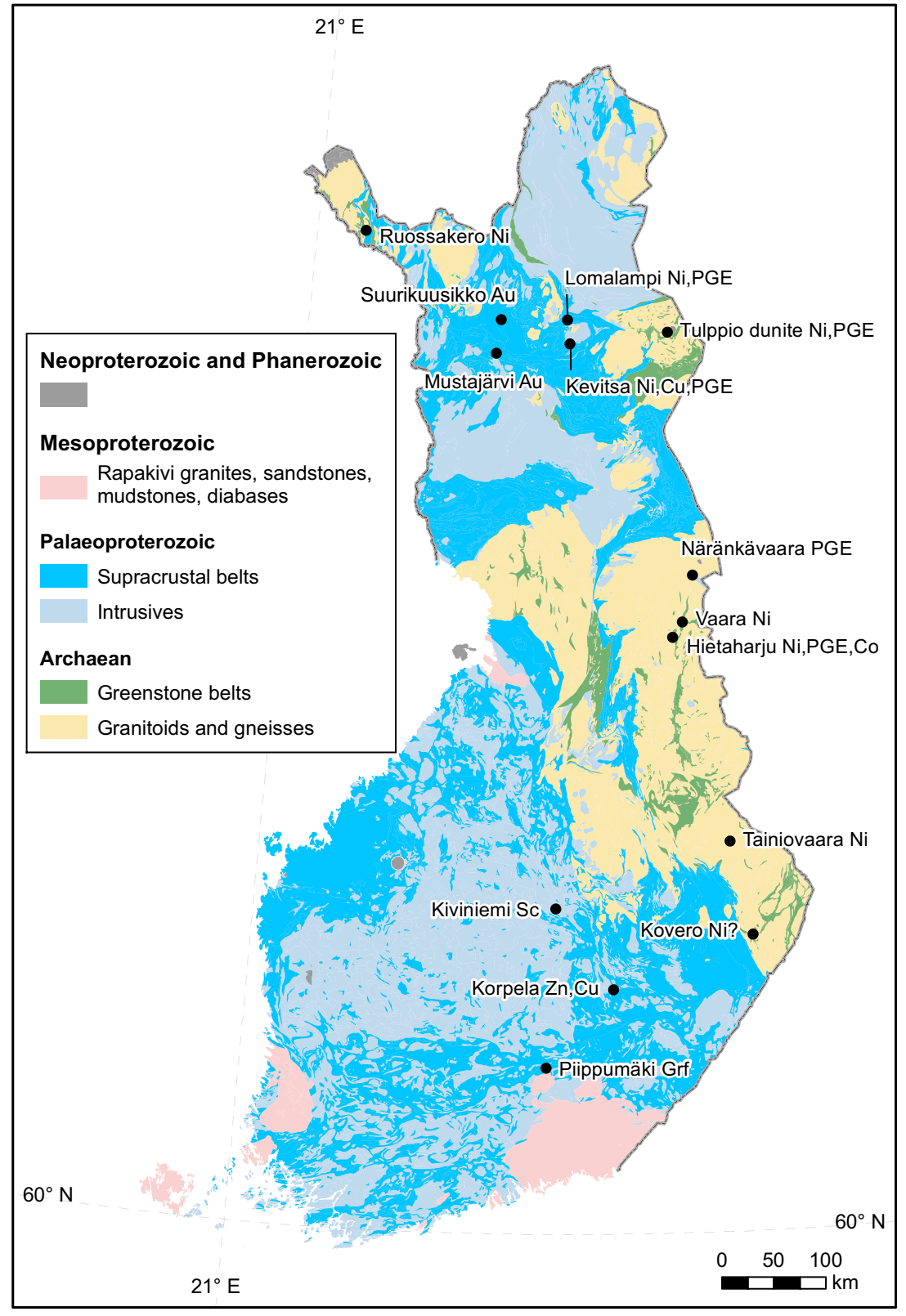

et al. 2015; Makkonen et al. 2017). The recent exploration in the area has revealed that the layered series in the Näränkävaara intrusion consists of a thick peridotitic-to-pyroxenitic ultramafic zone, and a gabbronoritic-to-dioritic mafic zone. A currently subeconomic offset-type PGE reef occurs along the transition between the ultramafic and mafic zones, in a similar stratigraphic location as in the Munni Munni and the Great Dyke intrusions. The low rate of sulfide accumulation combined with silicate assimilation, as well as the influx of a possible PGEdepleted magma pulse during the formation of the reef diluted high-grade sulfides and prevented the formation of a highgrade PGE mineralisation.

Halkoaho and co-authors provide a description of a highly unusual Palaeoproterozoic Fe-Ti-P-enriched ferrodiorite intrusion that hosts a potentially world-class scandium resource. The Kiviniemi intrusion was emplaced during the post-kinematic stage of the Svecofennian orogeny. The authors propose that during magmatic differentiation, scandium behaved as an incompatible element over an unusually extended period of time due to its complexing with fluoride and phosphate. Only after saturation of fluorapatite, Sc started to behave compatibly, and was incorporated in high concentrations into ferrohedenbergitic clinopyroxene and ferropargasite and ferroedenite. At Kiviniemi, such amphiboles contain up to $0.2 \mathrm{wt} \% \mathrm{Sc}$. Generally, Sc deposits are related to laterites, placers, skarns (sensu lato) and greisens (Williams-Jones and Vasyukova 2018). The Kiviniemi intrusion, where Sc is incorporated into the lattice of Fe-rich silicates, is thus highly 
unusual. According to the resource estimate presented by Halkoaho and others, the intrusion hosts 13.4 Mt @ $163 \mathrm{~g} / \mathrm{t}$ $\mathrm{Sc}, 1730 \mathrm{~g} / \mathrm{t} \mathrm{Zr}$, and $81 \mathrm{~g} / \mathrm{t} \mathrm{Y}$. These values identify a significant Sc resource, and high in situ value of the Kiviniemi deposit. However, such in situ value should be treated with caution as it does not take into account any beneficiation costs. Regardless of its true economic value, Kiviniemi provides an interesting insight into behaviour of Sc during extreme fractional crystallisation of tholeiitic magma.

Hokka describes lithology, alteration, alteration-related chemical changes, and chemostratigraphy related to a recent $\mathrm{Cu}-\mathrm{Zn}$-Au discovery in the SE extension of the main VMS belt extending across central Finland (Mäki et al. 2015). This is also the first description of the Korpela deposit in the public domain. The work indicates that the tectonic setting of the hosting sequence is an evolved arc rift in, possibly, a continental back-arc environment. It also suggests ways to use lithogeochemical data in exploration for VMS deposits. The work done by Hokka strengthens the mineral system approach for the region and gives multiple tools in both local exploration and VMS prospectivity assessments in any metamorphosed terrain.

Sayab et al. describe tectonic setting and structural development of the Suurikuusikko orogenic gold deposit, and its satellite ore body $10 \mathrm{~km}$ to the north, in the Lapland greenstone belt (LGB). The deposit hosts the currently largest gold mine in Europe, the Kittilä Mine (Wyche et al. 2015; http:// agnicoeagle.fi/about-us/operation/), with a 2019 gold production of $186,000 \mathrm{oz}$. Using geophysical datasets from regional to detailed scales, UAV-based imaging, mineralogical, textural and structural investigation, and X-ray computed tomography scans, Sayab et al. unravel the complex structural development history of the deposit and the hosting sequence. This work explains the two distinct stages of gold mineralisation at and near Suurikuusikko, connects them to dated tectonic events (ca. 1.92-1.91 and 1.77-1.76 Ga; Molnár et al. 2018), and discusses implications for other gold deposits and occurrences across the LGB, the largest greenstone belt in Europe (Hanski and Huhma 2005; Niiranen et al. 2014). This model of connected mineralisation and deformation in a terrain is another tool for exploration and prospectivity assessment of orogenic gold mineral systems.

Another orogenic gold prospect of the LGB is presented by Müller and others. The mineralised zone at Mustajärvi is a promising exploration target, and it is classified as an 'orogenic gold occurrence with atypical metal association' due to the unusual enrichment of $\mathrm{Te}, \mathrm{Co}$, and $\mathrm{Ni}$. The paper presents and discusses observations on the mineralogy and geochemistry of ore and hydrothermal alteration and the structural setting of the quartz-pyrite-tourmaline veins at Mustajärvi. Gold is exclusively concentrated in telluride minerals (calaverite and montbrayite) which is a rather unusual feature in orogenic gold systems. The average Co content in the analysed samples is $440 \mathrm{ppm}$ and enriched zones contain up to $2860 \mathrm{ppm} \mathrm{Co}$. However, no cobalt minerals were found and the major carrier of cobalt is pyrite. Similar epigenetic-hydrothermal gold deposits and occurrences are not uncommon in the LGB and also in the Kuusamo and Peräpohja belts in northern Finland, and currently they are in the focus of new exploration interest, partly due to their elevated Co contents.

Palosaari et al. describe in detail a Palaeoproterozoic flaky graphite prospect, Piippumäki, Eastern Finland. Graphite occurs within high-T low-P granulite facies gneisses that have been subjected to retrogressive greenschist metamorphism. Palosaari et al. have chosen a multidisciplinary approach to examine the prospect in detail. The methods range from project scale mapping and electromagnetic surveys to geochemical investigation, and to detailed evaluation of the morphology and crystallinity of graphite itself using SEM, XRD, and Raman spectroscopy. Raman thermometer-derived equilibration temperatures of graphite have been compared with PT conditions calculated for the host rocks using thermodynamic constraints (Perple_X software). Based on their study, the graphite in the Piippumäki prospect is of good quality flaky graphite with highly ordered structure. Generally, such highly crystalline graphite with only little impurities is believed to occur only in high-grade metamorphic terranes. The important outcome of the work of Palosaari et al. is that the highly ordered structure of the Piippumäki graphite was not affected by extensive retrograde metamorphism, implying that the graphitisation process was irreversible. This observation extends the search space for high-quality graphite deposits substantially, as they seem to be present also in lower-grade metamorphic terrains as long as they were earlier subjected to high metamorphic temperatures.

Acknowledgements We thank Editor-in-Chief Bernd Lehmann for agreeing to publish this collection of papers on mineral deposit research in Finland. We are grateful to all authors for the contributions. We deeply appreciate the work by the reviewers of the manuscripts submitted to this issue: Glenn Bark, Steve Barnes, Tim Bell, Anton Chakhmouradian, Jaroslav Dostal, Tobias Fusswinkel, Håvard Gautneb, Eero Hanski, Xiaoweng Huang, Marcello Imana, Stephen Johnston, Dan Kontak, Laura Lauri, Kirsti Loukola-Ruskeeniemi, Jukka-Pekka Ranta, Dennis Schlatter, John Slack, Holly Stein, Shenghong Yang. PE and FM also thank Geological Survey of Finland for allocating working time for our editorial work. Special thanks go to Jussi Pokki for drafting Fig. 1.

\section{References}

Eilu P (2012) Mineral deposits and metallogeny of Fennoscandia. Geological Survey of Finland, Spec Pap 53. https://tupa.gtk.fi/ julkaisu/specialpaper/sp_053.pdf

Eilu P, Hallberg A, Bergman T, Bjerkgård T, Feoktistov V, Klyucharev D, Korsakova M, Krasotkin S, Lampio E, Lauri L, Litvinenko V, Philippov N, Sandstad JS, Shchiptsov V (2020) Fennoscandian ore deposit database. Annual update. https://www.gtk.fi/en/ fennoscandian-mineral-deposits-application-ore-deposits-databaseand-maps/ 
Hanski E, Huhma H (2005) Central Lapland greenstone belt. In: Lehtinen M, Nurmi PA, Rämö OT (eds) Precambrian bedrock of Finlandkey to the evolution of the Fennoscandian shield. Elsevier, Amsterdam, pp 139-193. https://doi.org/10.1016/S0166-2635(05) 80005-2

Iljina M, Maier WD, Karinen T (2015) PGE-(cu-Ni) deposits of the Tornio-Näränkävaara belt of intrusions (Portimo, Penikat, and Koillismaa). In: Maier WD, Lahtinen J, O'Brien H (eds) Mineral deposits of Finland. Elsevier, Amsterdam, pp 134-164. https://doi. org/10.1016/B978-0-12-410438-9.00005-4

Maier WD (2015) Geology and petrogenesis of magmatic Ni-Cu-PGECr-V deposits: an introduction. In: Maier WD, Lahtinen R, O'Brien $\mathrm{H}$ (eds) Mineral deposits of Finland. Elsevier, Amsterdam, pp 7392. https://doi.org/10.1016/B978-0-12-410438-9.00003-0

Mäki T, Kousa J, Luukas J (2015) The Vihanti-Pyhäsalmi VMS belt. In: Maier WD, Lahtinen R, O'Brien H (eds) Mineral deposits of Finland. Elsevier, Amsterdam, pp 507-530. https://doi.org/10. 1016/B978-0-12-410438-9.00020-0

Makkonen HV, Halkoaho T, Konnunaho J, Rasilainen K, Kontinen A, Eilu P (2017) Ni-(cu-PGE) deposits in Finland - geology and exploration potential. Ore Geol Rev 90:667-696. https://doi.org/10. 1016/j.oregeorev.2017.06.008

Molnár F, Middleton A, Stein H, O’Brien H, Lahaye Y, Huhma H, Pakkanen L, Johanson B (2018) Repeated syn- and post-orogenic gold mineralization events between 1.92 and $1.76 \mathrm{Ga}$ along the Kiistala shear zone in the Central Lapland Greenstone Belt, northern Finland. Ore Geol Rev 101:936-959. https://doi.org/10.1016/j. oregeorev.2018.08.015

Molnár F, Eilu P, Lahtinen R, Niiranen T, Nykänen V, Rasilainen K, Sarala P, Sorjonen-Ward P (eds) (2020) Mineral systems in Finland: Orogenic gold. Geological Survey of Finland. https:// minsysfin.gtk.fi/. Accessed 10 Sept 2020
Niiranen T, Lahti I, Nykänen V, Karinen T (2014) Central Lapland Greenstone Belt 3D modelling project final report. Geological Survey of Finland Rep Invest 209. http://tupa.gtk.fi/julkaisu/ tutkimusraportti/tr_209.pdf

Rasilainen K, Eilu P, Halkoaho T, Heino T, Huovinen I, Iljina M, Juopperi H, Karinen T, Kärkkäinen N, Karvinen A, Kontinen A, Kontoniemi O, Kousa J, Lauri LS, Lepistö K, Luukas J, Makkonen H, Manninen T, Niiranen T, Nikander J, Pietikäinen K, Räsänen J, Sipilä P, Sorjonen-Ward P, Tiainen M, Tontti M, Törmänen T, Västi K (2016) Assessment of undiscovered metal resources in Finland. Ore Geol Rev 86:896-923. https://doi.org/ 10.1016/j.oregeorev.2016.09.031

Stedman A, Yunis J, Aliakbari E (2020) Fraser Institute annual survey of mining companies 2019. Fraser Institute, Vancouver www. fraserinstitute.org

Weihed P, Arndt N, Billström C, Duchesne JC, Eilu P, Martinsson O, Papunen H, Lahtinen R (2005) Precambrian geodynamics and ore formation: the Fennoscandian Shield. Ore Geol Rev 27:273-322. https://doi.org/10.1016/j.oregeorev.2005.07.008

Williams-Jones AE, Vasyukova OV (2018) The economic geology of scandium, the hunt of the rare earth element litter. Econ Geol 113: 973-988. https://doi.org/10.5382/econgeo.2018.4579

Wyche NL, Eilu P, Koppström K, Kortelainen VJ, Niiranen T, Välimaa J (2015) The Suurikuusikko gold deposit (Kittilä mine), northern Finland. In: Maier WD, Lahtinen R, O'Brien H (eds) Mineral deposits of Finland. Elsevier, Amsterdam, pp 411-434. https://doi.org/ 10.1016/B978-0-12-410438-9.00016-9

Publisher's note Springer Nature remains neutral with regard to jurisdictional claims in published maps and institutional affiliations. 